heyond the verumontanum. Introduction of the straight tube to this point is practically always readily performed without the production of any trauma. The introduction of the tube byond this point in occasional cases is accomplished with some difficulty, owing to the rather acnte ascent of the posterior part of the prostatic urethra to the vesical orifice. When the tube, after passing some distance through the prostatic wrethra, encounters resistance, one is practically always beyond the verumontanum. On moving the obturator one readily recognizes from the $\mathrm{Y}$-shape of the urethral orifice that the and of the tube lies towards the vesical end of the verumontanum. The tube is then gradually withdrawn until the readily recognized rerumontanum bobs into view. The tube is withdrawn until the anterior face of the verumontanum projects into the open portion of the tube. The mucous membrane is earefully and gently sponged with cotton swabs. The above position of the tube causes a tilting forward of the verumontanum so that the utricular orifice, which lies rather on the upper surface, cones directly facing the open end of the tube. The tip of the syringe can now be readily introsluced into the orifice of the utricle, the contents of the utricle aspirated for microscopic examination, and injection readily made into its cavity. Not infrequently, owing to the edematous condition of the mucous membrane, the utricular orifice is not visible, but with gentle probing with the tip of the syringe in the middle towards the upper surface one will rarely have difficulty in accomplishing catheterization.

silver nitrate has been the drug employed almost entirely, and it seems to give the most satisfactory results. While one can employ for external applications to the verumontanum silver nitrate in very concentrated solution, or the actual caustie, without the production, as a rule, of severe reactions, these strong injections are not well tolerated when given into the utricle. In patients with numerous neuralgic pains, the result of utricular disease. it is well to begin with injections of 1 per cent. and gradually increase the strength to 2 or 3 per cent. The employment of too strong a solution may cause intense pain lasting over several days. The injection should be given slowly, as forcible distention may be quite painful.

The reaction produced by too strong injections frequently reproduces in a striking manner the different neuralgic pains of which the patient has complained. When 1 to 3 per cent. solutions of silver nitrate are employed the injections may be repeated at intervals of from five to seven days, but when stronger injections are employed they shonld not be repeated more frequently than every two to three wceks.

Painful ejaculation, according to Wossidlo, is due to a scolerosed condition of the lower ent of the ejaculatory ducts leading to more or less contracture. The forcofil cmptying of the seminal fluid through these narrowed inflamed ducts produces the pain which occurs, and in many cases the pain is so severe that the patient is forced to refrain from coitus. It seems probable, howcrer, on account of the frequeney with which one or both of the ejaculatory ducts open on the floor of the prostatic utricle, that when the seminal fluid is thrown into this cavity the sudden distention of the inflamed utricular wall may produce the sudden sharp pain occurring at the moment of ejaculation.

II cmatospermia, which is seen in the absence of rlis(risce of the seminal vesicles, may resuit from congestion of the utricular wall. In one case of hematospermia appiration of the utricular contents showed a considerable amount of bloody fluid.

The benefits ascribed to irrigation and injection of the vasa deferentia by some authors are probably cxplained in many ases by the flushing out of the prostatic utricle, which occurs owing to the fact of the ejacvlatory ducts opening so commonly on the floor of the utricle. The good effects in these cases cannot result from the washing out of the seminal vesicles, as it is questionable whether the fluid injected into the vas finds its way to any extent into the cavity of the seminal vesicles, owing to their anatomic structure.

Dribbling of urine following the act of urination I have seen in many cases without any explainable cause. No stricture, sclerosed condition of the posterior urethra, pathologic conditions of the prostate or spinal corr trouble, could be demonstrated. In many cases observed, the dribbling has been a great annoyance to the patient and rebellions in responding to the usual forms of treatment. In four such cases in whom no improvement was obtained, as a result of dilatations, electric applications, massage, etc., the dribbling has been entirely relieved by applications to the verumontanum and utricle injections. In two of these cases only slight improvement followed treatment of the verumontanum, but they responded rapidly and promptly to treatment of the utricle. 'The explanation of this does not seem clear. Infection of the utricle not infrequently is the cause of persistent recurring posterior urethritis. One case of persistent posterior urethritis, due to the colon bacillus, which had resisted during several years all efforts to dislodge the infection, on careful urethroscopy of the posterior urethra showed pus oozing from the prostatic utricle. Injections of 1 to 2 per cent. silver nitrate into the utricle was very soon followed by a complete disappearance of the infection. Another patient with persistent posterior gonorrheal urethritis, who had been under treatment many months, was finally cured by the same procedure. Infection in the prostatic utricle is probably the cause of many cases resistant to ordinary forms of treatment. In some cases, particularly when the orifice of the utricle is small, it is well to snip out a wedge-shaper? piece of the utricular roof, thus affording better drainagc. This can be done by means of scissors devised by Young for excision of portions of the rerumontanum.

\section{AN IMPROVED GRAVITY APPARATUS FOR THE INTRAVENOUS INJECTION OF SALVARSAN}

\section{JOSEPH L. BOEHM, M.D.} ST, LOUIS

My improved gravity apparatus for the intravenous injection of salvarsan seems to overcome and solve many of the difficulties which, as reports have shown, are connected with this method. The aim is to avoid getting any of the solution into the subcutaneous tissues before the needle enters the lumen of the rein. The several syringes and forms of air-pressure apparatus already on the market have proved far from satisfactory, and leave much to be desired in the way of a perfect technic. $\mathrm{My}$ apparatus is portable, can be disconnected in all parts of the stand, and by a thurrb-screw allows of lowering and elevating the containers to any desired level, so as to control the rapidity of the flow of the solution into the vein. No solution which is not absolutely clear and sterile should be introduced into a vein. Clearness is to be obtained only by filtration through sterile filterpaper. In my experience very commonly the salvarsan solution contains some foreign flocculent particles; and there is also danger of small particles of glass being chipped off, if glass beads are used in the mixing cylinder; even if a mortar and pestle are used to triturate the salvarsan, such flocculency commonly exists. 
Two grarluated glass containers of 250 c.c. capacity are used. Into one is poured 150 to 200 c.c. of sterile salrarsan solution. The other is filler with a like volume of sterile saline solution (made with sterile distilled water and chemically pure sodium (hlorid).

The saline solution is allowed to flow out of the needle so as to expel ail air from the tube. The stopcock is now reversed, allowing the salvarsan solution to flow out of the needle, thereby expelling all air from its respective tulbing. The stop-cock is now reversed to its former position, until the saline solution is running in a slow even stream from the needle. The desired site of puncture is selected on the arm or at the elbow, and the needle is gently pushed or thrust through the skin into the rein. Meanwhile the saline solution is continuously running from it. The needle is held at about an angle of 10 to 15 degrees to the skin surface, depending on the prominence and caliber of the vein. Care must be exercised not to push the needle through both walls of the vein. This can he avoided by not introducing ton long a surface of the necdle into the tissues.

The patient previously has his arm carefully cleansed, a ligature in the form of an ordinary soft rubber catheter or tubing is tied around the middle of the arm, abore the selected site of puncture, and the patient is requesterl to tighten the fist. to make the superficial veins more prominent.

As soon as the needle has entered the rein, the rubber ligature is released by an assistant, the stop-cock of the needle is reversed, and the salvarsan solutinn flows through the needle into the rein. Hence, there is no dinger of any salvarsan solution getting into the subcutanesus tissues. No injection should be given intravenously in less than about ten minutes, and the solution must be quite warm when poured into the container so as to allow for its cooling when poured into the apparatus; when it enters the rein, the solution should be about the temperature of the blood. $\Lambda$ ideal intravenous injection is painless.

The needle will not produce cramping of the hand of the onerator, as the thumb and middle fingers pass through the rings, and the index-finger rests on the corrugater plate on its superior surface, thus affording firm support and preventing the needle from changing position after it has entered the vein, which may occur if the patient coughs or sneezes. It affords a firm and comfortable hold, even if the operator wears rubber gloves, as I have invariably done in all my work in this line.

Another adrantage of this neclle is that the stop-cock is readily adjusted. While the needle is being introduced into the rein, blood must not be allowed to flow out of the rein and enter the tube containing the salvarsan solution. Blood entering the needle at any time except when the saline solution is constantly flowing out of the needle would have a tendency to clot in it quickly and block its lumen.

715 North Eighth Street.

\section{THE SANITARY INSPECTION OF OYSTER- GROUNDS IN THE UNITEI STATES *}

\section{A. FUller. PH.D.}

Assistant Professor of Racteriology, Iniversity of Wisconsin MADISON, Wis.

The oyster industry forms a cery important part of the marine fisheries of the United States. The market value of the products of the fisheries of this country (exclusive of Alaska) for the year 1908 was estimatei by the Burcau of the Census ${ }^{1}$ at $\$ 54,030,630$. The income derived from the oyster trade alone, for the same year, amounted to $\$ 15, \% 13,000$, or nearly one-third the value of the total fishery products of the country.

The American oyster, Ostrea virginia, is found along the entire Atlantic coast from Maine to Texas. Two local varieties of oysters are also found on the Pacific coast. But the center of the oyster trade in America is confined to the Atlantic and Gulf states. The value of the product from these latter states amounted to $\$ 15$.019,360 for 1908 , while the output from the Pacific states for the same period marketed $\$ 695,640$. Twentyone states are interested in orster production to a greater or less extent, the larger producers being Maryland, Virginia, Connecticut, Louisiana, New York and New Jersey. In 1908, Maryland marketed 6,231,967 bushels of oysters; Virginia, 5,075,014 bushels; Connecticut, $3,948,0 \% 0$ bushels; Louisiana, $3,650,456$ bushels: and New Jersey and New York about two and a half million bushels each. South Carolina, Georgia, Rhode Island, Mississippi and Florida produced over 1,000,000 bushels each. The ten other oyster-growing states, with the exception of Maine and Oregon. marketed over 100,000 bushels each. In 1908 the orster crop of the Lnited States amounted to $33,329,920$ bushels in mar.ket and seed oysters.

No very recent statistics on the extent of the oyster industry in other countries than the United States have been obtained, and in this connection reference is made to the data published by G. W. Fuller, ${ }^{2}$ in 1905. 'This writer estimates the annual production of the United States at 28,138,434 bushels; of Great Britain at $2, \approx 60,000$ bushels; of France at $2,000,000$ bushels: of Holland at 70,000 bushels; and of the other orsterproducing countries at 610,580 bushels. From the abore figures it would appear that the United States is by far the largest producer, and supplies the market annually with more than fire times as many of these shell-fish as all the other oyster-producing countries combined. But, as is pointed out by Fuller, "these figures are not strictly comparable, as they refer in various instances to different years, beginning about 1890, and extending down to the present time (1905). But they serve to convey a general impression as to the relative extent of this important industry."

\footnotetext{
* From the Department of Bacteriology and Hygiene, Iniversity Wisconsin.

* Read before the Second International Congress of Alimentary Hygiene and of the Rational Alimentation of Man Brussels, Octo ber. 1910 .

1. Prolininary IReport of the Bureau of the Census on the Fish ries of the U. S. for the roar ending Dec. 31, 1908.
}

2. Fuller, G. W.: Jour. Franklin Inst., August, 1905 